УДК 316.613:334.722-051

DOI https://doi.org/10.26661/2310-4368/2021-1-16

\title{
ОСОБЛИВОСТІ КОМУНІКАТИВНИХ ЯКОСТЕЙ СУБ'СКТІВ ПІДПРИЄМНИЦЬКОЇ ДІЯЛЬНОСТІ
}

\author{
Шевченко Н. Ф. \\ доктор психологічних наук, професор, \\ завідувач кафедри педагогіки та психології освітньої діяльності \\ Запорізький національний університет \\ вул. Жуковського, 66, Запоріжжя, Україна \\ orcid.org/0000-0002-5297-6588 \\ shevchenkonf.20@gmail.com
}

\begin{abstract}
Ключові слова: комунікативні якості особистості, суб' $є к т$ підприємницької діяльності, спілкування, комунікативна компетентність, стиль спілкування, стратегія самопред'явлення у спілкуванні, комунікативна саморегуляція.
\end{abstract}

У статті представлено результати емпіричного дослідження особливостей комунікативних якостей суб'єктів підприємницької діяльності. На підставі аналізу підприємницької діяльності та особливостей професійного спілкування розроблена модель комунікативних якостей у суб'єктів підприємницької діяльності. Визначені комунікативні якості складають три блоки, які виявляються у всіх аспектах комунікативної діяльності підприємців: комунікативній, інтерактивній та перцептивній.

Блок «Комунікативно-соціальна компетентність» включає в себе такі якості: комунікабельність, конкретність мислення, емоційна врівноваженість, нормативність поведінки, домінантність, самоконтроль. Блок «Стиль професійно-діяльнісного спілкування» визначається певним орієнтаційним стилем, який домінує у професійно-діяльнісному спілкуванні підприємця. Блок «Комунікативна саморегуляція» характеризує стратегії самопред’явлення підприємця у спілкуванні.

Вивчення комунікативно-соціальної компетентності засвідчило, що у досліджуваних, які працюють в сферах продажу і послуг, на високому рівні розвинені комунікабельність, конкретність мислення (розвиненість логічного мислення, кмітливість), нормативність поведінки (реалістичність, раціональність), домінантність (перевага власних рішень, незалежність, орієнтованість на себе). У підприємців, зайнятих у сфері послуг, також виявлено високий рівень емоційної стабільності та самоконтролю.

Дослідження орієнтаційних стилів професійно-діяльнісного спілкування показало, що у підприємців, зайнятих у сфері продажу, переважають стилі орієнтації на дію та на перспективу. У підприємців, зайнятих у сфері послуг, переважними виявилися стилі спілкування $з$ орієнтацією на людей i на перспективу.

Вивчення особливостей комунікативної саморегуляції показало, що у респондентів обох груп переважає високий рівень здатності до управління самопред’явленням у спілкуванні - суб'єкти підприємницької діяльності вміють добре регулювати свою поведінку і робити іï відповідною до ситуації. Під час дослідження було підтверджено припущення про те, що комунікативні якості суб'єктів підприємницької діяльності як єдність універсальних комунікативних якостей особистості (комунікативносоціальна компетентність, стиль професійно-діяльнісного спілкування та комунікативна саморегуляція) мають характерні особливості залежно від типу підприємницької діяльності. 


\title{
FEATURES OF THE COMMUNICATIVE QUALITIES OF SUBJECTS OF ENTREPRENEURIAL ACTIVITY
}

\author{
Shevchenko N. F. \\ Doctor of Psychology, Professor, \\ Head of the Chair of Pedagogics and Psychology of Education \\ Zaporizhzhia National University \\ Zhukovskoho str., 66, Zaporizhzhia, Ukraine \\ orcid.org/0000-0002-5297-6588 \\ shevchenkonf.20@gmail.com
}

Key words: communicative personal qualities, subject of entrepreneurial activity, communication, communicative competence, communication style, strategy of self-presentation in communication, communicative self-regulation.
The article presents results of an empirical study of features of the communicative qualities of subjects of entrepreneurial activity. Based on the analysis of entrepreneurial activity and features of professional communication, a model of communicative qualities of entrepreneurial activity subjects has been developed. Certain communicative qualities contain three blocks, which are manifested in all aspects of communicative activity of entrepreneurs communicative, interactive and perceptual.

The block "Communicative and social competence" includes the following qualities: sociability, concreteness of thinking, emotional balance, normative behavior, dominance, self-control. The block "Style of professional communication" is determined by a certain orientation style or a combination of them, which dominates in the professional communication of an entrepreneur. The block "Communicative self-regulation" characterizes the strategies of selfpresentation of an entrepreneur in communication.

The study of communicative and social competence of entrepreneurs has shown their high level of sociability, concreteness of thinking (developed status of logical thinking, intelligence), normative behavior (realism, rationality), dominance (superiority of own decisions, independence, self-orientation). Entrepreneurs engaged in the service sector have also demonstrated a high level of emotional stability and self-control.

The study of orientation styles of professional communication has shown that entrepreneurs engaged in sales are characterized by styles of orientation to action and perspective. Entrepreneurs engaged in the service sector have preferred communication styles with a focus on people and perspective.

The study of communicative self-regulation has shown that respondents of both groups have a high level of ability to manage self-presentation in communication entrepreneurs are able to regulate their behavior and make it appropriate to the situation. The study has confirmed the assumption that communicative personal qualities of subjects of entrepreneurial activity as a unity of universal communicative personal qualities (communicative and social competence, style of professional communication and communicative self-regulation), have specific features depending on the type of entrepreneurial activity.
Постановка проблеми. Перспективи інтеграції України у Свропейську співдружність потребують суттєвих кроків у розбудові національної економіки. Однією з головних проблем сучасної економіки України є залучення громадян до іiі розвитку. Ключовою фігурою, що впливає на розвиток вітчизняної економіки, безумовно, є підприємець. Налаштованість громадян на оволодіння підприємництвом потребує особливої психоло- гічної підтримки й нерідко корекції прийнятих рішень щодо особистісних детермінант професійної підготовки [7].

Враховуючи глобальні тенденції нестабільності соціально-економічної ситуації, збільшення професійних і психічних навантажень у професійній діяльності, зростання конкуренції в суспільстві, особливо гостро постає проблема професійного спілкування, зокрема, комунікатив- 
них якостей суб'єктів підприємницької діяльності. Реалізуючись протягом усієї життєдіяльності, спілкування лежить в основі ефективності реалізації практично усіх процесів розвитку людини. Поінформованість про закономірності, властиві спілкуванню, відкриває широкі можливості для побудови програм управління комунікативними процесами, що сприяють підвищенню якості міжособистісного взаємодії у різних життєвих і професійних ситуаціях.

У межах психологічних проблем функціонування та розвитку сучасного підприємництва зарубіжними та українськими вченими насамперед вирішуються такі питання: культура підприємницької діяльності та особливості особистості підприємця [4]; підвищення ефективності підприємницької діяльності [5]; психологічна сутність підприємницької діяльності $[8 ; 11]$; окремі аспекти підприємництва $[10 ; 15]$; соціопсихологічний аналіз підприємницької діяльності [9], надійність суб'єктів підприємницької діяльності [14].

Вивченням проблеми комунікативних якостей (комунікативної компетентності) особистості менеджерів і підприємців займалися Н.Ш. Акаєва [1], С.Т. Джанерьян [2], В.М. Кустов [6]. Визнання того, що професія накладає відбиток на комунікативні якості особистості, стимулювало дослідження конкретних професійних груп.

Попри представленість робіт із вивчення комунікативних виявів підприємців, аналіз літератури засвідчив дефіцит наукових праць, у яких би висвітлювалася проблема комунікативних якостей як складного інтегрального утворення, що включає в себе єдність універсальних комунікативних якостей особистості. Виявлення цих інваріантів дозволить розробити практичні заходи зі сприяння розвитку комунікативних якостей підприємців.

Метою статті $\epsilon$ висвітлення результатів емпіричного дослідження особливостей комунікативних якостей суб' єктів підприємницької діяльності.

Виклад основного матеріалу дослідження 3 обгрунтуванням отриманих наукових результатів. У психологічній науці спілкування розглядається як взаємодія двох (або більше) людей, спрямоване на узгодження та об'єднання їх зусиль 3 метою налагодження відносин і досягнення загального результату. Будучи цілісним поведінковим актом, спілкування має досить складну організацію, що містить три взаємопов'язані сторони: комунікативну, інтерактивну і перцептивну [9]. В рамках підприємницької діяльності реалізуються усі зазначені аспекти спілкування.

Комунікативна сторона спілкування у сфері підприємництва полягає в обміні між задіяними у ньому сторонами інформацією, що дозволяє реа- лізувати товарно-грошовий обмін. Інтерактивна сторона спілкування у сфері підприємництва полягає в тому, що сторони реалізують спрямовану один на одного активність, що представляє співпрацю чи конкуренцію з метою оптимізації бізнесу. Перцептивна сторона спілкування у сфері підприємництва виявляється в пізнанні його учасниками інтересів, схильностей, намірів протилежної сторони та інших психологічних факторів, що лежать в основі здійснення бізнес-операцій [1].

Комунікативні якості особистості розглядаються як система психологічних характеристик людини, наявність яких визначає успішність вирішення комунікативних завдань. Успішність спілкування виявляється у досягненні і збереженні психологічного контакту 3 партнером 3 метою стабілізації міжособистісних відносин на їх оптимальної стадії розвитку; досягнення сумісності, згоди, взаємної пристосованості і задоволеності шляхом гнучкого коригування цілей, вмінь і станів, способів впливу відповідно до тих змін обставинами [3].

Комунікативні якості підприємця мають структуру, у складі якої можна виділити якості, що дозволяють йому для вирішення бізнес-завдань впливати на позицію інших людей, вирішувати регулятивні завдання щодо самого себе, інших людей і самої процедури спілкування. На підставі здійсненого аналізу підприємницької діяльності [9-11] та особливостей професійного спілкування $[1 ; 6 ; 7]$ нами розроблена модель комунікативних якостей в суб'єктів підприємницької діяльності. Визначені комунікативні якості складають три блоки, які виявляються в усіх аспектах комунікативної діяльності підприємців: комунікативній, інтерактивній та перцептивній.

Блок «Комунікативно-соціальна компетентність» включає в себе такі якості: комунікабельність, конкретність мислення, емоційна врівноваженість, нормативність поведінки, домінантність, самоконтроль. Блок «Стиль професійно-діяльнісного спілкування» визначається певним орієнтаційним стилем або їх поєднанням, які домінують у професійно-діяльнісному спілкуванні підприємця. Блок «Комунікативна саморегуляція» характеризує стратегії самопред'явлення підприємця у спілкуванні.

В основу дослідження покладено припущення про те, що комунікативні якості суб' єктів підприємницької діяльності як єдність універсальних комунікативних якостей особистості (комунікативно-соціальна компетентність, стиль професійно-діяльнісного спілкування та комунікативна саморегуляція) мають характерні особливості залежно від типу підприємницької діяльності.

Дослідницьку вибірку склав 51 суб’єкт підприємницької діяльності (37 чоловіків і 14 жінок 
віком від 30 до 53 років) зі стажем роботи від 5 років. За змістом бізнесу респондентів було розділено на дві підгрупи: підприємці, які працюють у сфері продажів - 29 осіб; підприємці, які працюють у сфері послуг - 22 особи.

Психодіагностичний інструментарій склали такі методики: «Діагностика комунікативної соціальної компетентності» (авт. М.П. Фетіскін, В.В. Козлов, Г.М. Мануйлов [12]); «Орієнтаційні стилі професійно-діяльнісного спілкування» (авт. О.В. Морозов [12]); «Здатність до управління самопред'явленням у спілкуванні» (авт. М. Снідер, адапт. Н.В. Амяга [13]); математико-статистичні методи обробки експериментальних даних на базі пакету статистичних програм IBM SPSS-20 (обчислення середніх значень,

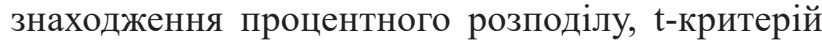
Стьюдента).

Розглянемо результати дослідження відповідно до структурної організації комунікативних якостей підприємців.

Комунікативна компетентність - здатність особистості, що базується на знанні, чуттєвому досвіді, інтуїції, орієнтації в ситуаціях професійного спілкування, готовності розуміти мотиви, тенденції, стратегії поведінки як свої власні, так і інших осіб, орієнтуватися в ситуаціях спілкування. Згідно з отриманими даними, за фактором А для респондентів обох досліджуваних груп характерна значна перевага комунікабельності (відкритості) над замкненістю (ізольованістю) - 16,28 балів (I група); 18,36 балів (II група). Представники сфер продажу і послуг мають загальну схильність до взаємно корисних і приємних контактів з іншими людьми, здатність до встановлення міцних і доброзичливих взаємин $з$ оточуючими.

За фактором В у досліджуваних обох груп на високому рівні переважає конкретність мислення (розвиненість логічного мислення, кмітливість) над абстрактністю мислення (неуважністю, слаборозвиненістю логічного мислення) - 14,93 балів (I група); 14,86 балів (II група). Тобто, підприємці характеризуються схильністю до всього підходити розумно; перш ніж зробити що-небудь, вони схильні оцінювати можливі шанси, хитро і вміло будувати свою поведінку. Досліджувані характеризуються великою різноманітністю інтелектуальних інтересів, прагненням бути добре поінформованими з приводу політичних, наукових, навіть життєвих проблем, недовірою авторитетам, терпимістю до суперечностей і неясного, критичністю мислення. Не приймаючи на віру ніяку інформацію, вони 3 високою ймовірністю ставляться до всього досить скептично, намагаються усе проаналізувати і зрозуміти самі.

За фактором C у досліджуваних I групи (підприємці сфери продажу) зафіксовано рівновагу між емоційною врівноваженістю (емоційною стійкістю, зрілістю, спокійністю) та емоційною рухливістю (емоційною нестійкістю, мінливістю) - 11,48 балів. У досліджуваних II групи (підприємці сфери послуг) емоційна врівноваженість значно перевищує емоційну нестійкість 15,14 балів. Це свідчить про те, що група підприємців, зайнята у сфері послуг, вирізняється більшою емоційною зрілістю, спокоєм, упевненістю в собі, постійністю у своїх планах і уподобаннях; респонденти мало піддаються випадковим коливанням настрою (не переймаються через дрібниці), сміливо дивляться в обличчя фактам, сприймають навколишнє серйозно і реалістично, добре усвідомлюють вимоги дійсності, не приховують від себе власних недоліків, відчувають себе добре пристосованими.

За фактором Д в обох досліджуваних групах виявлено рівновагу між двома протилежними особистісними якостями: стриманістю (тверезістю, мовчазністю, серйозністю) та експресивністю (життєрадісністю, безтурботністю, веселістю) 12,72 балів (I група); 12,14 балів (II група). Згідно 3 отриманими балами, респондентам не чужі емоційні вияви, але здебільшого вони знаходяться під самоконтролем. У спілкуванні 3 великою ймовірністю виявляють себе як досить уважні, намагаються зрозуміти більше, ніж сказано співрозмовником словами. Здебільшого вони вважають за краще делікатно не висловлювати свою точку зору, не будучи впевненими, що вона буде прийнята. Можна припустити також властиве цій категорії людей переживання труднощів у прогнозі розвитку відносин між людьми. Відсутність розкутості почуттів може перешкодити підприємцям повноцінного сприйняття людей.

За фактором К у респондентів обох груп на достатньому рівні переважає нормативність поведінки (реалістичність, раціональність) над піддатливістю почуттям (емпатія, чутливість, художність мислення) - 14,52 балів (І група); 14,73 балів (II група). Це означає, що досліджувані підприємці у спілкуванні характеризуються розвиненою коректністю, ввічливістю і відстороненістю, схильністю до всього підходити розумно і не сентиментально; перш ніж зробити що-небудь вони схильні оцінювати можливі шанси, хитро і вміло будувати свою поведінку. Маючи високі показники за фактором нормативності, підприємці 3 високою ймовірністю характеризуються настороженістю, недовірою, наполегливістю, схильністю до упередження, очікування від усіх підступу.

За фактором М у респондентів обох груп на високому рівні зафіксовано перевагу домінантності (перевага власних рішень, незалежність, орієнтованість на себе) над залежністю (залежність від групи, слідування за громадською дум- 
кою) - 17,03 балів (I група); 18,23 балів (II група). Переважання фактора домінантності з високою ймовірністю свідчить про сміливість, енергійність, активність, прагнення жити за власними законами і міркуваннями, схильність агресивно відстоювати свої права на самостійність і вимагати прояви самостійності від оточуючих; досліджувані воліють усе робити самі: самі приймають рішення, домагаються їх виконання, несуть відповідальність; вони готові пожертвувати будьякими зручностями, тільки б зберегти свою незалежність.

За фактором Н для респондентів I групи характерна рівновага між двома протилежними особистісними якостями - самоконтролем та імпульсивністю (неорганізованістю) - 12,86 балів. У досліджуваних II групи (підприємці сфери послуг) самоконтроль значно перевищує імпульсивність - 16,41 балів. Таким чином, підприємці, зайняті в сфері послуг, продемонстрували наявність високого рівня терпимості до оточуючих, який виявляється як у взаємодії з партнерами, так і з клієнтами. Їх «видатною» комунікативною властивістю є здатність досить добре регулювати свою поведінку і робити іiі відповідною до ситуації, тобто виявляти гнучкість поведінки та iii варіативність у різних ситуаціях.

Слід зауважити, що за такими досліджуваними параметрами зафіксовано високі оцінки відповідного фактора та вираженість певної якості (числовий діапазон 16-20 балів): комунікабельність (в обох групах), домінантність (в обох групах), самоконтроль (у II групі).

Розглянемо результати вивчення орієнтаційних стилів професійно-діяльнісного спілкування респондентів. Згідно з отриманими даними, у підприємців, зайнятих у сфері продажів, переважають стилі орієнтації на дію $(16,66$ балів - високий рівень прояву) та на перспективу $(17,28$ балів високий рівень вияву). Для стилю орієнтації на дію характерне обговорення результатів, конкретних питань, поведінки, відповідальності, досвіду, досягнень, рішень. Респонденти, які володіють цим стилем, прагматичні, прямолінійні, рішучі, легко переключаються 3 одного питання на інше, часто схвильовані.

У підприємців, зайнятих у сфері послуг, переважними виявилися стилі спілкування 3 орієнтацією на людей $(16,14$ балів - високий рівень вияву) та на перспективу $(17,18$ балів - високий рівень вияву). Для стилю спілкування 3 орієнтацією на людей характерне обговорення людських потреб, мотивів, почуттів, «духу роботи в команді», розуміння, співпраці. Особи 3 цим стилем зазвичай емоційні, чутливі, співчутливі і психологічно орієнтовані. Отримані високі показники значною мірою свідчать про наявність здат- ності до автентичної взаємодії з оточуючими, до саморозкриття в процесі міжособистісного спілкування. Включаючись до спілкування з різними за рольовою позицією суб'єктами, підприємці, які надають послуги, насамперед орієнтовані на особистісну форму спілкування.

Стиль спілкування 3 орієнтацією на перспективу, як було зазначено, домінуе в обох групах респондентів. Суб'єктам підприємницької діяльності з цим стилем властиве обговорення концепцій, великих планів, нововведень, різних питань, нових методів, альтернатив. Вони володіють хорошою уявою, сповнені ідей, але мало реалістичні і часом їх складно розуміти.

Стиль спілкування 3 орієнтацією на процес виражений в обох групах досліджуваних на середньому рівні (13,28 балів - I; 13,41 балів - II). Для респондентів, яким притаманний цей стиль, характерно обговорення фактів, процедурних питань, планування, організації, контролю, деталей. Особа, яка володіє цим стилем, орієнтована на систематичність, послідовність, ретельність; вона чесна, багатослівна і малоемоційна. Можна припустити, що цей тип спілкування більш властивий підприємцям, які займаються певним виробництвом: це робить їх менш публічними $\mathrm{i}$ контактними, ніж їх колеги, зайняті у сферах продажів і послуг.

Перейдемо до аналізу результатів, отриманих за методикою М. Снідер [13]. Згідно з отриманими даними, у респондентів обох груп переважає високий рівень здатності до управління самопред'явленням у спілкуванні - 65,52\% від загальної кількості досліджуваних I групи; 72,72\% від загальної кількості досліджуваних II групи. Це означає, що обстежені суб'єкти підприємницької діяльності вміють добре регулювати свою поведінку і робити іiі відповідною до ситуації. Їх поведінка характеризується гнучкістю та широким діапазоном варіативності для різних ситуацій.

Показники в інтервалі помірного рівня здатності до управління самопред'явленням у спілкуванні отримали $34,48 \%$ досліджуваних I групи та $22,72 \%$ досліджуваних II групи. Показники в межах низького рівня зафіксовано у незначній кількості в II групі (4,55\% від загальної кількості). Зазвичай низький рівень здатності до управління самопред'явленням у спілкуванні характеризує осіб, які приділяють мало уваги інформації, що сигналізує про відповідне самопред'явлення в певній соціальній ситуації. Їх репертуар самопред'явлення не надто широкий, а поведінка задається швидше внутрішніми емоційними станами та установками, а не стилем і особливостями конкретної ситуації.

М. Снідер [13] виділив два типи особистостей: «прагматичну» та «принципову». Людина 
демонструє відповідний до свого типу особистості тип самопред'явлення, що відображає швидше внутрішні характеристики (у «принципової особистості») або відповідно до ситуативних особливостей (у «прагматичної»). Отже, за досліджуваною комунікативною якістю респондентів обох груп можна охарактеризувати як осіб, які добре вміють управляти виробленим враженням.

Діяльність у кожній зі сфер бізнесу має свою специфіку, яка накладає відбиток на розвиток певних комунікативних якостей особистості. Так, в рамках бізнесу у сфері продажів переважає спілкування з клієнтами та колегами по бізнесу; спрямованість спілкування на переконання покупця; висока частка творчого компонента; наявність ситуацій вибору між етичними нормами і матеріальною вигодою; необхідність побудови рекламних впливів. У рамках бізнесу з надання послуг переважає спілкування 3 клієнтами, підлеглими, колегами по бізнесу; важливість сприйняття i розуміння бажань клієнта; значущість самопрезентації; висока частка творчого компонента; наявність екстремальних ситуацій спілкування.

Для визначення статистично достовірних відмінностей у показниках вияву комунікативних якостей у підприємців, які працюють в сферах продажів i послуг, ми використали t-критерій Стьюдента. Було визначено статистично достовірні відмінності в показниках комунікативних якостей підприємців за такими параметрами:

1) фактор С (емоційна врівноваженість - емоційна нестійкість): підприємці сфери послуг характеризуються більшою емоційною врівноваженістю $\left(t_{\text {eun }}=2,86 ; \mathrm{p} \leq 0,01\right)$;

2) фактор Н (самоконтроль - імпульсивність): підприємці сфери послуг характеризуються більшим рівнем самоконтролю $\left(t_{\text {eun }}=3,50 ; \mathrm{p} \leq 0,01\right)$;

$3)$ орієнтація на дію $\left(t_{\text {eum }}=2,59 ; \mathrm{p} \leq 0,05\right)$ : у підприємців, зайнятих у сфері продажів, більше виражений стиль спілкування 3 орієнтацією на дію;

4) орієнтація на людей $\left(t_{\text {eun }}=2,90 ; \mathrm{p} \leq 0,01\right)$ : у підприємців, зайнятих у сфері послуг, більше виражений стиль спілкування з орієнтацією на людей.

Таким чином, за результатами проведеного дослідження можна сказати, що особливості комунікативних якостей підприємців, зайнятих у сфері продажу і послуг, - дуже схожі у зв'язку з досить високим рівнем розвитку певних якостей, але мають і деякі розбіжності.

Так, підприємці, зайняті в сфері продажу, мають загальну схильність до взаємно корисних і приємних контактів з іншими людьми; виявляють домінантність і наполегливість. Характеризуються схильністю до всього підходити розумно, 3 оцінкою можливих шансів, здатні хитро і вміло будувати свою поведінку. Респонденти мало під- даються впливу інших людей, виявляють певний ступінь настороженості і недовіри. Підприємці, зайняті в сфері продажу, досить реально оцінюють свою роль у колективі, орієнтуються на дотримання загальноприйнятих норм поведінки. Ïх стиль професійно-діяльнісного спілкування свідчить про прагматичність, прямолінійність, рішучість, варіативність поведінки.

Підприємці, які реалізують різні послуги, виявляють високий ступінь комунікабельності, емоційну зрілість, спокій, несхильність до випадкових коливань настрою, впевненість у собі, сталість у планах і уподобаннях. Свою діяльність вони випереджають плануванням оцінкою можливих шансів на успіх. Респондентам властива енергійність, домінантність, активність, самостійність від оточуючих. Вони характеризуються розвиненою коректністю, ввічливістю і відстороненістю, схильністю до всього підходити розумно і не сентиментально.

Володіючи високим рівнем самоконтролю, вони виявляють його як у взаємодії з партнерами, так і з клієнтами. Їх стиль професійно-діяльнісного спілкування свідчить про орієнтованість на пристосування до партнера по спілкуванню. Включаючись у спілкування з різними за рольовою позицією суб'єктами, вони орієнтовані на його особистісну форму, вміють досить добре регулювати свою поведінку і робити іiі відповідною до ситуації.

Під час дослідження було підтверджено припущення про те, що комунікативні якості суб'єктів підприємницької діяльності як єдність універсальних комунікативних якостей особистості (комунікативно-соціальна компетентність, стиль професійно-діяльнісного спілкування та комунікативна саморегуляція) мають характерні особливості залежно від типу підприємницької діяльності.

Висновки і перспективи подальших розробок у цьому напрямі. Вивчення комунікативно-соціальної компетентності підприємців засвідчило, що у досліджуваних обох груп на високому рівні розвинені комунікабельність, конкретність мислення (розвиненість логічного мислення, кмітливість), нормативність поведінки (реалістичність, раціональність), домінантність (перевага власних рішень, незалежність, орієнтованість на себе). У підприємців, зайнятих у сфері послуг, також виявлено високий рівень емоційної стабільності та самоконтролю.

Дослідження орієнтаційних стилів професійно-діяльнісного спілкування показало, що у підприємців, зайнятих у сфері продажу, переважають стилі орієнтації на дію та на перспективу. У підприємців, зайнятих у сфері послуг, переважними виявилися стилі спілкування 3 орієнтацією на людей і на перспективу. 
Для стилю спілкування 3 орієнтацією на перспективу, який домінує в обох групах респондентів, властиво обговорення концепцій, великих планів, нововведень, різних питань, нових методів, альтернатив. Вивчення особливостей комунікативної саморегуляції показало, що у респондентів обох груп переважає високий рівень здатності до управління самопред'явленням у спілкуванні - суб'єкти підприємницької діяльності вміють добре регулювати свою поведінку і робити її відповідною до ситуації. Їх поведінка характеризується гнучкістю та широким діапазоном варіативності для різних ситуацій.

За результатами проведеного дослідження зроблено висновок, що особливості комунікативних якостей підприємців, зайнятих у сфері продажу і послуг, із досить високим рівнем розвитку певних якостей, але мають статистично підтверджені характерні особливості. Перспективним напрямом розвитку наукової проблематики надалі вважаємо емпіричне дослідження специфіки комунікативних якостей підприємців у гендерному та віковому аспектах.

\section{ЛІТЕРАТУРА}

1. Акаева Н.Ш. Психологические условия развития коммуникативных свойств личности предпринимателя : дисс. канд. психол. наук. Сочи, 2008. 207 с.

2. Джанерьян С.Т., Рудакова С.В., Ничепуренко Л.В. Опыт изучения личностных особенностей представителей частного сектора экономики. Психологическая адаптация личности к условиям рыночной экономики. Ростов н/Д : ЮРГИ, 1999. С. 217-227.

3. Жигайло Н.І. Психологія бізнесу, лідерства та комунікацій як перспективний науковий напрям в Україні та Європі. Вісник Львівського університету. Серія: Психологічні науки. 2018. Випуск 3. C. $103-108$.

4. Извеков А.И., Завьялова Е.К., Посохова С.Т. Свобода как основополагающий принцип культуры предпринимательства. Российское предпринимательство. 2019. Т. 20. № 4. С. 873-890. doi: $10.18334 /$ rp.20.4.40533.

5. Карамушка Л.М., Креденцер О.В., Філь О.А. Система діагностичних методик для вивчення психологічних особливостей підприємницької діяльності. Актуальні проблеми психологї : зб. наукових пращь Інституту психології ім. Г.С. Костюка АПН Украӥни. К. : Міленіум, 2005. Том 1. Ч. 14. С. 10-16.

6. Кустов В.Н. Развитие коммуникативной компетентности менеджеров коммерческих организаций по оптовым продажам : дисс. канд. психол. наук. Москва, 2007. 172 с.

7. Лантух I.В., Лантух В.В. Психологічний портрет суб'єктів підприємницької діяльності. Fundamental and applied researches in practice of leading scientific schools. Issue: Volume 32, Number 2, 2019. Co-publ.: Publishing office: Accent Graphics Communications. Hamilton, ON, 2019. P. 3-10.

8. Москаленко В.В. Підприємництво як предмет дослідження економічної психології. Актуальні проблеми психологї̈ : зб. наукових прачь Інституту психологї̈ ім. Г.С. Костюка АПН України. К. : Міленіум, 2003. Том 1. Ч. 11. С. 17-20.

9. Пачковський Ю.Ф. Психологія підприємництва : навч. посіб. К. : Каравела, 2018. 416 с.

10. Підприємництво: психологічні, організаційні та економічні аспекти : навч. посіб. / С.Д. Максименко, А.А. Мазаракі, Л.П. Кулаковська, Т.Ю. Кулаковський. К. : Київ. нац. торг.-екон. ун-т, 2012. $720 \mathrm{c}$.

11. Поздняков В.П., Филинкова Е.Б. Психология успешного предпринимательства: опыт исследования и практической работы. Прикладная психология. 1998. № 5. С. 32-43.

12. Фетискин Н.П., Козлов В.В., Мануйлов Г.М. Социально-психологическая диагностика развития личности и малых групп. М. : Институт Психотерапии, 2002. 490 с.

13. Шкуратова И.П. Самопредъявление личности в общении : монография. Ростов н/Д : Изд-во ЮФу, 2009. $192 \mathrm{c}$.

14. Lantukh I. Research of Cognitive Style of Enterprises With Different Level of Personal Reliability. Innovations in science: the challenges of our time : monograph. Hamiltion. Otario. Canada. 2018. P. $155-162$.

15. Urban B. Entrepreneurial cognitions: Linking willingness and ability expert scripts to self-efficacy and new venture creation decisions. SA Journal of Industrial Psychology. 2008. Vol. 34. № 3. P. 22-28.

\section{REFERENCES}

1. Akayeva N.Sh. (2008). Psikhologicheskiye usloviya razvitiya kommunikativnykh svoystv lichnosti predprinimatelya [Psychological conditions for the development of the communicative properties of an entrepreneur's personality] : Candidate's thesis Sochi. 207 [in Russian].

2. Dzhaneryan S.T., Rudakova S.V. \& Nichepurenko L.V. (1999). Opyt izucheniya lichnostnykh osobennostey predstaviteley chastnogo sektora ekonomiki. Psikhologicheskaya adaptatsiya lichnosti k usloviyam 
rynochnoy ekonomiki [Experience in studying the personal characteristics of representatives of the private sector of the economy. Psychological adaptation of the individual to the conditions of a market economy]. Rostov n/D : YURGI. 217-227 [in Russian].

3. Zhyhaylo N.I. (2018). Psykholohiya biznesu, liderstva ta komunikatsiy yak perspektyvnyy naukovyy napryam v Ukrayini ta Yevropi [Psychology of business, leadership and communications as a promising scientific field in Ukraine and Europe]. Visnyk Lvivskoho universytetu - Bulletin of Lviv University. Seriya psykholohichni nauky. Vyp. 3. 103-108 [in Ukrainian].

4. Izvekov A.I., Zavyalova Ye.K. \& Posokhova S.T. (2019). Svoboda kak osnovopolagayushchiy printsip kultury predprinimatelstva [Freedom as a fundamental principle of the culture of entrepreneurship]. Rossiyskoye predprinimatelstvo - Russian entrepreneurship. 20 (4). 873-890. doi: 10.18334/rp.20.4.40533 [in Russian].

5. Karamushka L.M., Kredentser O.V. \& Fil O.A. (2005). Systema diahnostychnykh metodyk dlya vyvchennya psykholohichnykh osoblyvostey pidpryyemnytskoyi diyalnosti [System of diagnostic methods for studying the psychological features of entrepreneurial activity]. Aktualni problemy psykholohiyi : zb. naukovykh prats' Instytutu psykholohiyi im. H.S. Kostyuka APN Ukrayiny - Actual problems of psychology: coll. scientific works of G.S. Kostyuk Institute of Psychology of the Academy of Pedagogical Sciences of Ukraine. K. : Milenium, 1 (14). 10-16 [in Ukrainian].

6. Kustov V.N. (2007). Razvitiye kommunikativnoy kompetentnosti menedzherov kommercheskikh organizatsiy po optovym prodazham [The development of the communicative competence of managers of commercial organizations for wholesale sales] : Candidate's thesis. Moscow. 172 [in Russian].

7. Lantukh I.V. \& Lantukh V.V. (2019). Psykholohichnyy portret subyektiv pidpryyemnytskoyi diyalnosti [Psychological portrait of business entities]. Fundamental and applied researches in practice of leading scientific schools. Issue: Volume 32, Number 2. Co-publ.: Publishing office: Accent Graphics Communications. Hamilton, ON. 3-10 [in Ukrainian].

8. Moskalenko V.V. (2003). Pidpryyemnytstvo yak predmet doslidzhennya ekonomichnoyi psykholohiyi [Entrepreneurship as a subject of study of economic psychology]. Aktualni problemy psykholohiyi : zb. naukovykh prats' Instytutu psykholohiyi im. H.S. Kostyuka APN Ukrayiny - Actual problems of psychology : coll. scientific works of G.S. Kostyuk Institute of Psychology of the Academy of Pedagogical Sciences of Ukraine. K. : Milenium. 1 (11). 17-20 [in Ukrainian].

9. Pachkovskyy YU.F. (2018). Psykholohiya pidpryyemnytstva [Psychology of entrepreneurship] : navch. posib. K. : Karavela. 416. [in Ukrainian].

10. Maksymenko S.D., Mazaraki A.A., Kulakovska L.P. \& Kulakovskyy T.YU. (2012). Pidpryyemnytstvo: psykholohichni, orhanizatsiyni ta ekonomichni aspekty [Entrepreneurship: psychological, organizational and economic aspects] : navch. posib. K. : Kyyiv. nats. torh.-ekon. un-t. 720 [in Ukrainian].

11. Pozdnyakov V.P. \& Filinkova Ye.B. (1998). Psikhologiya uspeshnogo predprinimatelstva: opyt issledovaniya i prakticheskoy raboty [The Psychology of Successful Entrepreneurship: Research Experience and Practical Work]. Prikladnaya psikhologiya-Applied Psychology. 5. 32-43 [in Russian].

12. Fetiskin N.P., Kozlov V.V. \& Manuylov G.M. (2002). Sotsialno-psikhologicheskaya diagnostika razvitiya lichnosti i malykh grupp [Socio-psychological diagnostics of personality and small group development]. M. : Institut Psikhoterapii. 490 [in Russian].

13. Shkuratova I.P. (2009). Samopredyavleniye lichnosti v obshchenii : monografiya [Self-presentation of personality in communication : monograph]. Rostov n/D : YUFu. 192 [in Russian].

14. Lantukh I. (2018). Research of Cognitive Style of Enterprises With Different Level of Personal Reliability. Innovations in science: the challenges of our time : monograph. Hamiltion. Otario. Canada. 155-162.

15. Urban B. (2008). Entrepreneurial cognitions: Linking willingness and ability expert scripts to self-efficacy and new venture creation decisions. SA Journal of Industrial Psychology. Vol. 34. № 3. P. 22-28. 